\title{
PENGARUH PENAMBAHAN SARI WORTEL PADA YOGHURT DITINJAU DARI AW, KADAR AIR, VISKOSITAS, TOTAL ASAM TERTITRASI DAN KADAR PROTEIN
}

\author{
Dimas Fajar Nugroho, Desna Ayu Wijayanti \\ Akademi Peternakan Karanganyar. Jl. Lawu No 115 Karanganyar.Telp (0271) 495212 \\ email : fajarresmi@gmail.com
}

\begin{abstract}
Abstrak
Yoghurt merupakan salah satu bentuk produk minuman dari pengolahan susu yang memanfaatkan mikroba (Streptococcus thermophillus dan Lactobacillus bulgaricus.) dalam proses fermentasi susu segar menjadi produk emulsi semi padat, selain itu yoghurt juga memiliki kandungan nutrisi yang tinggi salah satunya pada protein dan rendah lemak. Tujuan dari penelitian ini untuk mengetahui presentase penambahan sari wortel yang optimal untuk meningkatkan kualitas yoghurt dilihat pada activity water (AW), Viskositas, Total Asam Tertitrasi dan Kadar Air. Bahan yang digunakan adalah susu sapi, sari wortel dan starter plain yoghurt. lodin, alkohol $75 \%$ dan aquades. Metode yang digunakan dalam penelitian ini adalah metode eksperimen dengan Rancangan Acak Kelompok (RAK) dengan 5 perlakuan yaitu penambahan sari wortel pada yoghurt dengan konsentrasi $0 \%, 10 \%, 15 \%, 20 \%$, dan $25 \%$ volume susu (1 liter), dengan masing-masing perlakuan diulangi sebanyak 4 kali. Analisis data menggunakan sidik ragam / ANOVA (Analysys of Variance), dilanjutkan dengan Uji Jarak Berganda Duncan. Hasil penelitian menunjukkan bahwa penambahan sari wortel pada yoghurt dapat meningkatkan nilai nilai Aw: P0 $(0,9)$ menjadi P4 $(0,96)$, kadar air: P0 $(88,96 \%)$ menjadi P4 $(92,58 \%)$, nilai total asam tertitrasi :P0 (0,57\%) menjadi P4 (0,67\%) dan nilai kadar protein: P0 $(2,97 \%)$ menjadi P4 (4,89\%), pada nilai viskositas mengalami penurunan dari P0 (216,75 cP) menjadi P4 (148,00 $\mathrm{cP})$. Berdasarkan analisis penelitian dapat disimpulkan bahwa penggunaan jus wortel dengan konsentrasi $15 \%$ memberikan hasil terbaik pada yoghurt dengan nilai Aw (0,94), kadar air $(91,21 \%)$, viskositas $(177,75$ $\mathrm{cP})$, total asam tertitrasi $(0,65 \%)$, dan kadar protein $(4,26 \%)$.
\end{abstract}

Kata kunci : Air, Sari Wortel, Yogurt

\begin{abstract}
Yogurt is a form of beverage product from milk processing that utilizes microbes (Streptococcus thermophillus and Lactobacillus bulgaricus.). In the fermentation process of fresh milk into a semi-solid emulsion product, yogurt also has high nutritional content, one of which is protein. And low in fat. The purpose of this study was to determine the optimal percentage of addition of carrot juice to improve the quality of yogurt in terms of water activity (AW), viscosity, total titrated acid and water content. The ingredients used are cow's milk, carrot juice and plain yogurt starter. lodine, $75 \%$ alcohol and distilled water. The method used in this research is experimental method Comletely Block Design of 5 treatments, namely the addition of carrot juice to yogurt with a concentration of $0 \%, 10 \%, 15 \%, 20 \%$, and $25 \%$. Volume of milk (1 liter), with each treatment repeated 4 times. Data analysis used ANOVA (Analysis of Variance), followed by Duncan's Multiple Range Test. The results showed that the addition of carrot juice to yogurt could increase the value of Aw: P0 (0.9) to P4 (0.96), water content: P0 (88.96\%) to P4 (92.58\%), the total acid value. Titration: P0 (0.57\%) to P4 (0.67\%) and protein content value: P0 (2.97\%) to P4 $(4.89 \%)$, the viscosity value decreased from P0 (216.75) cP) becomes P4 (148.00 cP). Based on the research analysis, it can be concluded that the use of carrot juice with a concentration of $15 \%$ gives the best results for yogurt with a value of $\mathrm{Aw}(0.94)$, water content $(91.21 \%)$, viscosity $(177.75 \mathrm{cP})$, total acid titrated $(0,65 \%)$, and protein content $(4.26 \%)$.
\end{abstract}

Keyword: carrot juice,yoghurt, water 


\section{PENDAHULUAN}

Yoghurt merupakan produk fermentasi susu yang diberikan tambahan bakteri asam laktat. Pembuatan yoghurt dilakukan dengan fermentasi bakteri Streptococcus thermophillus dan Lactobacillus bulgaricus. Yoghurt dikonsumsi karena kesegaran dan aromanya yang khas. Cita rasa yang khas pada yoghurt disebabkan karena proses fermentasi. Yoghurt mempunyai kelebihan untuk penderita lactose intolerance karena selama proses pembuatan yoghurt, kadar gula susu turun. Yoghurt merupakan minuman yang banyak dikonsumsi masyarakat karena rasanya yang nikmat, kandungan gizinya baik, sebagai sumber probiotik dan yoghurt juga bermanfaat dalam mengatasi gangguan saluran pencernaan.

Yoghurt secara umum terbagi menjadi plain yoghurt yaitu yoghurt tanpa penambahan rasa dan fruit yoghurt yaitu yoghurt dengan penambahan rasa buah, namun yoghurt dengan penambahan sari sayuran masih sedikit sehingga kami melakukan diversifikasi pada proses pembuatannya, yaitu dengan penambahan sari wortel. Wortel sebagai bahan pangan juga memiliki kandungan gizi tinggi yang diperlukan oleh tubuh dan dapat menanggulangi masalah defisiensi vitamin (Mariance, 2006). Pada proses pembuatan yoghurt sari wortel, mengakibatkan susu akan mengalami perubahan sifat fisikokimia meliputi kadar air, viskositas, Aw, total asam tertitrasi dan kadar protein. Kadar air yoghurt yang meningkat seiring dengan peningkatan penambahan sari wortel yang ditambahkan. Yoghurt dengan penambahan rasa akan meningkatkan cita rasa dan konsumen (Wulandari dan Setiyadi, 2010)

\section{BAHAN DAN METODE}

Penelitian ini dilaksanakan di Laboratorium Akademi Peternakan Karanganyar. Pengambilan data penelitian ini dilakukan pada bulan juni 2020.
Bahan yang digunakan adalah susu sapi, sari wortel dan starter plain yoghurt. Iodin, alkohol $75 \%$ dan aquades.

\section{Metode Penelitian}

Metode yang digunakan adalah percobaan menggunakan Rancangan Acak Lengkap (RAL) dengan 4 ulangan dan 5 perlakuan. Kombinasi perlakuan dalam penelitian ini adalah sebagai berikut: penambahan sari wortel sebanyak P0 $(0 \%)$, P1 (10\%), P2 (15\%), P3 (20\%) dan P4 (25\%) dari volume susu.

\section{Tahap Penelitian}

Penelitian ini dilaksanakan dengan beberapa tahapan, tahapan penelitan kami sajikan sebagai berikut :

\section{Pembuatan Sari Wortel}

Wortel dihaluskan menggunakan juicer tanpa penambahan air, setelah wortel halus kemudian diambil sarinya dengan cara diperas dengan kalin halus atau kain saring sehingga keluar air perasan sari wortel yang bewarna oranye wortel.

\section{Pasteurisasi Susu}

Susu segar dimasukkan ke dalam panci dan dipasteurisasi dengan metode LTLT (Low Temperature Long Time) pada suhu $63^{\circ} \mathrm{C}$ selama 15 menit diatas kompor. Pengukuran suhu dengan menggunakan termometer.

\section{Pembuatan Yoghurt}

Susu segar sebanyak 1 liter ditambahkan sari wortel sesuai perlakuan yaitu $0 \%, 10 \%$, $15 \%, 20 \%$ dan $25 \%$ dari volume susu, kemudian dilakukan pasteurisasi pada suhu $63^{\circ} \mathrm{C}$ selama 15 menit. Setelah suhu mencapai $63^{\circ} \mathrm{C}$ dilakukan penurunan suhu hingga suhu mencapai $42^{\circ} \mathrm{C}$. Pada setiap perlakuan ditambah starter $5 \%$ (Lactobacillus bulgaricus dan Streptococcus thermophilus) dan diaduk kemudian ditutup rapat. Tahap selanjutnya, dilakukan inkubasi pada ruang selama 24 jam (Ace dan Supriyanto, 2006).

\section{Variable Pengamatan}

Variabel penelitian yang diamati adalah AW menggunakan metode Primo-Martin, Kadar Air menggunakan metode pengeringan (thermogravimetri), Viskositas menggunakan 
Agrisaintifika

Jurnal Ilmu-Ilmu Pertanian

Vol. 5, No. 1, 2021

Nugroho, et al. 2021

metode viskotester $6 \mathrm{R}$ Haake dengan spindel no 2, Total Asam Tertitrasi mengunakan metode titrasi dan Kadar Protein mengunakan metode spektrofotometri UV-Visible (biuret). prosedur pengujian sesuai dengan metode yang dituliskan dalam AOAC 2005.

\section{Analisis Data}

Data yang diperoleh dianalisis megunakan sidik ragam / ANOVA (Analysys of Variance). Apabila terdapat perbedaan pengaruh yang signifikan diantara perlakuan, maka dilanjutkan dengan Uji Jarak Berganda Duncan (Astuti, 2007).

\section{HASIL DAN PEMBAHASAN}

\section{Aktivitas Air (Aw)}

Penambahan sari wortel memberikan pengaruh yang sangat nyata (Tabel 1) terhadap Aw yoghurt. Aktivitas air yoghurt sari wortel mengalami peningkatan seiring bertambahnya pemberian sari wortel. Aw yoghurt tanpa penambahan sari wortel cukup sesuai yaitu 0,91 dan aktivitas air tertinggi yaitu 0,96 . Aw yoghurt dengan rata-rata 0,94 menunjukkan mikroba dapat tumbuh. Nilai Aw ini sesuai jika dibandingkan aktivitas air pada umumnya, berdasarkan Standar Nasional Indonesia (SNI) 01-6366-2000 merekomendasikan bahwa mikroba umumnya dapat tumbuh pada bahan pangan dengan Aw 0,6-0,99 (Afrilia dkk., 2012).

Hasil analisis ragam menunjukkan bahwa nilai Aw pada yoghurt sari wortel pada P4 sebesar 0,94 artinya mikroba masih dapat tumbuh dengan baik, karena nilai Aw yoghurt sari wortel masuk dalam nilai optimum pertumbuhan mikroba. Penambahan sari wortel pada yoghurt memberikan pengaruh yang sangat nyata terhadap Aw $(P<0,01)$. Kadar air yang semakin tinggi akan berpengaruh terhadap peningkatan Aw. Hal ini sesuai dengan pendapat Herawati (2008) kadar air dalam bahan pangan menentukan jumlah mikroba yang dapat berkembangbiak dalam bahan pangan. Aktivitas air merupakan jumlah air yang tersedia untuk pertumbuhan mikroba dalam pangan. Kondisi aktivitas air yang tinggi mempercepat oksidasi lemak dibandingkan kondisi aktivitas air yang lebih rendah. Lisa, Lutfi dan Susilo (2015) Hubungan kadar air dengan nilai Aw ditunjukkan dengan kecenderungan semakin tinggi kadar air maka semakin tinggi nilai Awnya. Nilai Aw dinyatakan dalam angka desimal pada kisaran skala 0-1,0. Perubahan pada kadar air berkaitan erat dengan Aw yang merupakan tempat pertumbuhan bakteri, khamir, kapang, jamur dan mikroba lainnya.

Tabel 1. Hasil Analisis AW, Kadar Air, Viskositas, Total Asam Tertitrasi dan Kadar Air

\begin{tabular}{cccccc}
\hline Perlakuan & AW & Kadar Air (\%) & Viskositas (cP) & $\begin{array}{c}\text { Total Asam } \\
\text { Tertitrasi }(\%)\end{array}$ & $\begin{array}{c}\text { Kadar Protein } \\
(\%)\end{array}$ \\
\hline (P0) 0\% & $0,91 \pm 0,09^{\mathrm{a}}$ & $88,96 \pm 2,98^{\mathrm{a}}$ & $216,75 \pm 72,53^{\mathrm{b}}$ & $0,57 \pm 0,08^{\mathrm{a}}$ & $2,97 \pm 0,70^{\mathrm{a}}$ \\
(P1) $10 \%$ & $0,92 \pm 0,01^{\mathrm{a}}$ & $90,31 \pm 0,59^{\mathrm{a}}$ & $183,50 \pm 44,91^{\mathrm{a}}$ & $0,63 \pm 0,13^{\mathrm{a}}$ & $3,44 \pm 0,80^{\mathrm{a}}$ \\
(P2) $15 \%$ & $0,94 \pm 0,02^{\mathrm{b}}$ & $91,21 \pm 0,63^{\mathrm{b}}$ & $177,75 \pm 65,06^{\mathrm{a}}$ & $0,65 \pm 0,04^{\mathrm{a}}$ & $4,26 \pm 1,00^{\mathrm{b}}$ \\
(P3) 20\% & $0,95 \pm 0,02^{\mathrm{c}}$ & $92,07 \pm 0,57^{\mathrm{b}}$ & $169,25 \pm 62,69^{\mathrm{a}}$ & $0,66 \pm 0,03^{\mathrm{a}}$ & $4,65 \pm 0,71^{\mathrm{c}}$ \\
(P4) 25\% & $0,96 \pm 0,01^{\mathrm{c}}$ & $92,58 \pm 0,59^{\mathrm{b}}$ & $148,00 \pm 25,44^{\mathrm{a}}$ & $0,67 \pm 0,08^{\mathrm{a}}$ & $4,89 \pm 0,64^{\mathrm{c}}$ \\
\hline
\end{tabular}

Keterangan: Notasi yang berbeda pada kolom yang sama menunjukkan pengaruh yang sangat nyata $(P<0,01)$

\section{Kadar Air}

Nilai ata-rata kadar air yoghurt paling tinggi $(92,58 \%)$ dihasilkan dari yoghurt dengan penambahan sari wortel sebesar $25 \%$ (P4) dan terendah sebesar $88,96 \%$ dari yoghurt dengan penambahan wortel $0 \%(\mathrm{P} 0)$. Nilai kadar air sangat bervariasi karena adanya perbedaan kualitas susu yang digunakan dalam pembuatan yoghurt. Askar dan Sugiarto (2005) kadar air sampel yoghurt bervariasi dari $71-90 \%$, variasi ini karena susu yang digunakan sebagai bahan dasar pembuatan yoghurt kualitasnya berbedabeda, ada yang encer dan ada yang kental. Proses pengolahannya berpengaruh terhadap 
produk akhir dari yoghurt. Makanjoula (2012) kadar air yoghurt berkisar pada 89,00$91,20 \%$.

Semakin banyak sari wortel yang ditambahkan maka kadar air dari yoghurt semakin meningkat karena kadar air sari wortel lebih tinggi dari pada kadar air susu. Celik, Bakirci dan Sat (2006) semakin tingginya kadar air maka nilai kekentalan rendah. Efek serupa ditemukan pada penambahan jus buah anggur dan buah cherry. Damarjana (2011) menambahkan bahwa semakin tinggi penambahan starter menyebabkan kadar air yoghurt semakin tinggi karena starter berupa cairan yang mengandung air, sehingga semakin banyak starter yang ditambahkan, maka semakin banyak air yang terkandung dalam yoghurt. Semakin tinggi nilai kadar air maka menyebabkan yoghurt mudah rusak.

\section{Viskositas}

Pengujian viskositas dilakukan untuk mengetahui tingkat kekentalan yoghurt sari wortel. Hasil analisis ragam menunjukkan bahwa penambahan sari wortel berpengaruh sangat nyata terhadap viskositas yoghurt $(\mathrm{P}<0,01)$. Hasil uji viskositas dinyatakan dalam satuan cP (centi poise). Viskositas yogurt (Tabel 1) tanpa penambahan sari wortel $0 \%(\mathrm{P} 0)$ menunjukkan hasil tertinggi yaitu $216,75 \mathrm{cP}$ dan viskositas terendah dengan penambahan sari wortel $25 \%$ (P4) yaitu $148,00 \mathrm{cP}$. Standar viskositas yoghurt sendiri belum ada akan tetapi rata-rata viskositas ini secara umum tidak jauh berbeda jika dibandingkan dengan produk yoghurt yang mempunyai nilai rata-rata viskositas sebesar 183- 241 cP (Fauzi, 2015). Nilai viskositas ini lebih tinggi jika dibandingkan hasil lainnya yaitu yoghurt memiliki nilai viskositas sebesar 8,28-13,00 cP (Winarno dan Fernandez, 2007), serta yoghurt dengan berbagai penstabil memiliki rata-rata viskositas 56,36-73,48 cP (Setianto, Pramono dan Ulyani, 2014).

Rata-rata hasil penelitian menunjukkan bahwa semakin bertambah pemberian sari wotel pada yoghurt menyebabkan viskositas semakin menurun. Penurunan nilai viskositas pada yoghurt sari wortel dipengaruhi oleh adanya penggunaan sari wortel pada yoghurt. Hal ini sama dengan pendapat Febrihantana dkk. (2012) semakin banyak sari wortel yang ditambahkan akan menyebabkan semakin besar jumlah kadar air bebas sehingga viskositasnya menurun. Manab (2008) nilai $\mathrm{pH}$ yang mendekati 4,6 akan menghilangkan kelarutan kasein sehingga mempengaruhi sifat fisik dari yoghurt yaitu viskositas.

\section{Total Asam Tertitrasi}

Hasil analisis ragam bahwa penambahan sari wortel memberikan pengaruh yang sangat nyata $(P<0,01)$. Total asam tertitrasi yoghurt tanpa penambahan sari wortel cukup sesuai yaitu $0,57 \%$ dan total asam tertitrasi tertinggi yaitu $0,67 \%$. Total asam tertitrasi yoghurt ini sesuai jika dibandingkan dengan total asam tertitrasi pada Standar Nasional Indonesia (SNI) umumnya yaitu 0,5-2,0\% (Anonimous, 2009), standarisasi nilai asam tertitrasi pada yoghurt menurut Codex min 0,6\% (Anonimous, 2003) dan

kadar total asam yoghurt pada pengamatan hari ke-0 sampai hari ke-15 berkisar 1,55$1,71 \%$ (Wahyudi, 2006).

Peningkatan total asam tertitrasi diduga karena berlangsungnya pertumbuhan BAL yang berkembang dan media tumbuhnya akibat penambahan nutrisi sari wortel seperti vitamin A. Hal ini sesuai dengan pendapat Septiani dkk. (2013), semakin banyak bakteri yang memproduksi asam laktat, maka semakin tinggi asam yang terbentuk. Peningkatan total asam tertitrasi ditandai dengan penurunun $\mathrm{pH}$ karena semakin banyak gula yang terhidrolisis menjadi asam. Kartikasari dan Nisa (2014) melaporkan bahwa peningkatan penambahan sari buah menyebabkan total asam.

\section{Kadar Protein}

Kadar protein pada yoghurt tanpa penambahan sari wortel menunjukkan hasil yang terendah yaitu $2,97 \%$, sedangkan kadar protein tertinggi yaitu $4,89 \%$. Kadar protein yoghurt ini sesuai jika dibandingkan dengan kadar protein pada umumnya menurut SNI 
yoghurt yang baik memiliki kandungan protein minimal 2,7\% (Anonimous, 2009), standarisasi protein yoghurt berdasarkan Canadian Dairy Commission sebesar 3,5$5,0 \%$ (Anonimous, 2002), kadar protein yoghurt pada pengamatan hari ke-0 sampai hari ke-15 berkisar antara 2,82-2,94\% (Wahyudi, 2006), sedangkan perlakuan terbaik adalah P4 dengan penambahan sari wortel $20 \%$ menghasilkan kadar protein $3,280 \%$ dan perlakuan P3 dengan konsentrasi penambahan 15\%menghasilkan kadar protein 2,718\% (Choiri, 2014). Penambahan sari wortel pada yoghurt memberikan pengaruh yang sangat nyata $(P<0,01)$. Penambahan sari wortel yang berbeda pada yoghurt menghasilkan kadar protein yang berbeda pada yoghurt, semakin banyak penambahan sari wortel semakin meningkat kadar protein yoghurt. Hal ini dikarenakan pertumbuhan BAL yang meningkat dari bahan sari wortel yang dimanfaatkan sebagai media tumbuh. Choiri (2014).

\section{SIMPULAN}

\section{Kesimpulan}

Penambahan sari wortel 15\% (P2) memberikan hasil terbaik pada yoghurt dengan nilai Aw $(0,94)$, kadar air $(91,21 \%)$, viskositas $(177,75 \mathrm{cP})$, total asam tertitrasi $(0,65 \%)$, dan kadar protein $(4,26 \%)$.

\section{Saran}

Perlu dilakukan penelitian lebih lanjut mengenai daya simpan yoghurt sari wortel.

\section{DAFTAR PUSTAKA}

Ace, I.S. dan S. Supriyanto. 2006. Pengaruh Konsentrasi Starter Terhadap Karakteristik Yoghurt. Jurnal Penyuluhan Pertanian, 1(1): 28-33.

Anonimous. 2002. Canadian Dairy Commission: The Nutritional Value Of Yoghurt. Canada. in. Anonimous. 2009. Minuman Susu Fermentasi Berperisa. SNI 2981-2009. Jakarta
Anonious. 2005. Official Method of Analysis of The Association of Official Analytical of Chemist (AOAC). Arlington (US): The Association of Official Analytical Chemist, Inc.

Askar, S. dan Sugiarto. 2005. Uji Kimiawi dan Organoleptik Sebagai Uji Mutu Yoghurt. Prosiding Temu Teknis Nasional Tenaga Fungsional Pertanian. Bogor.Astuti, 2007).

Celik, S., I. Bakirci and I.G. Sat. 2006. Physicochemical and Organoleptic Properties Of Yogurt With Cornelian Cherry Paste. International Journal of Food Properties, 9 (3): 401-408.Choiri, 2014

Darmajana, D. A. 2011. Pengaruh Konsentrasi Starter dan Konsentrasi Karagenan Terhadap Mutu Yoghurt Nabati Kacang Hijau. Jurnal Sains, Teknologi dan Kesehatan, 2(1): 267-274.

Fauzi, I. 2015. Pengaruh Penambahan Sari Wortel Pada Proses Pembuatan Yoghurt Ditinjau Dari Organoleptik, Kadar Air dan Viskositas. Fakultas Peternakan. Universitas Brawijaya. Malang.

Febrihantana W., L.E., Radiati dan I. Thohari. 2012. Pengaruh Penambahan Sari Wortel Sebagai Fortifikasi Produk Yogurt Ditinjau Dari Nilai pH, Total Asam Tertitrasi, Total Bakteri Asam Laktat, Viskositas dan Total Karoten. Fakultas Peternakan. Universitas Brawijaya. Malang.

Herawati, H. 2008. Penentuan Umur Simpan Pada Produk Pangan. Jurnal Litbang Pertanian, 27(4): 124-131.

Kartikasari, D.I. dan F.C. Nisa. 2014. Pengaruh Penambahan Sari Buah Sirsak dan Lama Fermentasi Terhadap Karakteristik Fisik dan Kimia Yoghurt. Jurnal Pangan dan Agroindustri, 2(4): 239-248.

Lisa, Lisa, M., M. Lutfi dan B. Susilo. 2015. Pengaruh Suhu dan Lama Pengeringan Terhadap Mutu Jamur Tiram Putih (Plaerotus ostreatus). Jurnal Keteknikan 
Agrisaintifika

Nugroho, et al. 2021

Pertanian Tropis dan Biosistem, 3(3): 270-279.)

Makanjoula, O.M. 2012. Production and Quality Evaluation Of Soy-Corn Yoghurt. Advance Journal Of Food. Science and Technology, 4(3):130-134.Manab (2008).

Mariance, R. 2006. Karakteristik Fisik dan pH Sari Wortel. Program Studi Fisika Fakultas Matematika dan IImu Pengetahuan Alam Institut Pertanian Bogor. Bogor.

Septiani, A.H., Kusrahayu dan A.M. Legowo. 2013. Pengaruh Penambahan Susu Skim pada Proses Pembuatan Frozen Yogurt yang Berbahan Dasar Whey terhadap Total Asam, pH dan Jumlah Bakteri Asam
Laktat. Animal Agriculture Journal, 2 (1): 225-231.

Wahyudi, M. 2006. Proses Pembuatan dan Analisis Mutu Yoghurt. Buletin Teknik Pertanian, 11(1): 12-16.

Winarno, F.G. dan I.E. Fernandez. 2007. Susu dan Produk Fermentasinya. Mbrio Press. Bogor.

Wulandari, E. dan W. Setiyadi. 2010. Karakteristik Stired Yogurt Mangga (Mangifera indica) dan Apel (Malus domestica) Selama Penyimpanan. Jurnal Pangan, $\quad$ 10(1): 20-24 